\title{
In Vivo Administration of Lymphocyte-specific Monoclonal Antibodies in Nonhuman Primates

\author{
Delivery of Ribosome-inactivating Proteins to Spleen and Lymph Node T Cells
}

\author{
Norman L. Letvin, Laura V. Chalifoux, Keith A. Reimann, Jerome Ritz, Stuart F. Schlossman, and John M. Lambert \\ Harvard Medical School, New England Regional Primate Research Center, Southborough, Massachusetts 01772; \\ and Division of Tumor Immunology, Dana Farber Cancer Institute, Boston, Massachusetts 02115
}

\begin{abstract}
The selective delivery in vivo of a $\mathbf{T}$ lymphocyte-specific monoclonal antibody and immunotoxin conjugates to $T$ cells in lymph node and spleen was assessed in rhesus monkeys. A transient coating of all $T$ lymphocytes in the lymph nodes and spleens of healthy rhesus monkeys could be achieved after infusion of unconjugated anti-T11. Because derivatized antibody is cleared more rapidly than unconjugated antibody, it was necessary to infuse a higher dose of immunotoxin than antibody alone to achieve saturation of the lymphocyte binding sites with antiT11. When sufficient antibody-toxin conjugate was infused, toxin was readily demonstrable on lymph node and spleen $T$ cells by $16 \mathrm{~h}$ after infusion. This demonstration that toxins can be successfully delivered with specificity to target $T$ cell populations in the monkey suggests that killing of restricted cell populations in vivo should be feasible.
\end{abstract}

\section{Introduction}

The exquisite specificity of monoclonal antibodies suggests that they should be useful therapeutically in the targeting of toxins and drugs to restricted cell populations in man (1-3). However, significant issues will require clarification before antibody-toxin and antibody-drug conjugates can be rationally used in human therapeutic trials. Their in vivo stability, clearance, and metabolic fate and the optimal dosing schedules for their delivery to target cells must be established. Furthermore, the successful delivery of toxins and drugs to target cell populations must be demonstrated and a toxic effect on these target cells must be shown.

The nonhuman primate provides an important model in which to explore these issues. Man and nonhuman primate species share many physiologic properties. Moreover, there is a remarkable conservation of cell surface antigens on their hematopoietic cells (4-8). Thus, an antibody-toxin or antibody-drug conjugate that binds to a restricted lymphocyte population in man can be studied in a nonhuman primate in which the structure recognized by that antibody is conserved.

We have recently initiated a series of studies in macaque monkeys on the in vivo use of monoclonal antibodies as therapeutic agents. As a model system we have been investigating antibodies that bind to the erythrocyte-rosette receptor (T11), a structure present on all mature T lymphocytes (9). We have

Received for publication 24 January 1986 and in revised form 4 April 1986.

J. Clin. Invest.

(c) The American Society for Clinical Investigation, Inc.

0021-9738/86/09/0666/08 \$1.00

Volume 78, September 1986, 666-673 explored the use of monoclonal anti-T11 antibodies, both unconjugated and chemically linked to the ribosome-inactivating proteins gelonin and saporin, which are potent inhibitors of protein synthesis in cell-free mammalian in vitro systems $(10,11)$. Because these A chain toxins are incapable of binding to cells, they are not toxic in vitro to intact cells (12). Gelonin and saporin, however, become cytotoxic when linked to antibodies, such as anti-T11, which bind to cell surface antigens (13).

In the present studies we have assessed our ability to deliver ribosome-inactivating proteins to $\mathrm{T}$ cell populations in lymph nodes and spleen in the monkey. We have found that these toxins can be targeted to restricted cell populations in the monkey when coupled to monoclonal antibodies and have defined some of the important conditions which must be met in order to achieve this in vivo delivery of toxins.

\section{Methods}

Animals. The monkeys used in this study were adult Macaca mulatta (rhesus) and ranged in weight from 4 to $10 \mathrm{~kg}$. They were maintained in accordance with the guidelines of the Committee on Animals of the Harvard Medical School and the "Guide for the Care and Use of Laboratory Animals" (DHHS Publication No. [NIH] 85-23, revised 1985).

Materials. 2-Iminothiolane $\mathrm{HCl}, \mathrm{N}$-succinimydil 3-(2-pyridyldithio) propionate (SPDP) ${ }^{1}$, and 1,3,4,6-tetra-chloro-3a,6a-diphenylglycoluril (Iodo-gen) were purchased from Pierce Chemical Co., Rockford, IL. Protein A-Sepharose CL-4B and bis-tris were obtained from Sigma Chemical Co., St. Louis, MO. [Methyl- ${ }^{3} \mathrm{H}$ ]-Thymidine $(2 \mathrm{Ci} / \mathrm{mmol})$ and ${ }^{125} \mathrm{I}-\mathrm{Na}$ (carrier-free, $100 \mathrm{mCi} / \mathrm{ml}$ in $0.1 \mathrm{M} \mathrm{NaOH}$ ) were purchased from Amersham Corp., Arlington Heights, IL. Goat anti-mouse IgG was obtained from Jackson Immuno Research Laboratories, Inc., Avondale, PA. Rabbit anti-gelonin and rabbit anti-saporin antiserum were prepared by injection of the purified proteins in complete Freund's adjuvant into New Zealand White rabbits (13).

Murine monoclonal antibody anti-T11. The antibody utilized in these studies was anti-T11 $1 \mathrm{~A}$, a monoclonal antibody of isotype IgG1 that reacts with the sheep erythrocyte rosette receptor, a determinant found on all resting human $T$ cells (9). It will hereafter be referred to simply as anti-T11. This antibody reacts with the homologous structure on $T$ cells from other primate species, including $M$. mulatta (5). The antibody was produced by hybridoma cells grown as ascites tumors in pristaneprimed BALB/c mice. It was purified by precipitation with $\left(\mathrm{NH}_{4}\right)_{2} \mathrm{SO}_{4}$, ion-exchange chromatography using carboxymethyl cellulose (CM-52; Whatman, Inc., Clifton, NJ), and by gel filtration through Sephacryl S-300 (Pharmacia Fine Chemicals, Piscataway, NJ) as described previously $(10,13)$. The antibody was judged pure by polyacrylamide/dodecyl sulfate gel electrophoresis and by isoelectrofocussing using PAG-plates (Ampholine, pH range 3.5-9.5) purchased from LKB Instruments, Inc.,

1. Abbreviations used in this paper: DAB, diamino benzidine; Iodo-gen, 1,3,4,6-tetra-chlora-3a,6a-diphenylglycoluril; SMCC, succinimidyl 4-( $N$ maleimidomethyl) cyclohexane-1-carboxylate; SPDP, $N$-succinimidyl 3-(2-pyridyldithio) propionate. 
Gaithersburg, MD. (13). The purified antibody was sterilized by filtration through Millex-GV filters ( $0.22 \mu \mathrm{m}$; Millipore Corp., Bedford, MA), and was tested for the presence of endotoxin using the Limulus Amebocyte Lysate Test (MA Bioproducts, Walkersville, MD). The B lymphocytespecific monoclonal antibody anti-B1 was prepared as previously described (13).

Ribosome-inactivating proteins. Seeds from Gelonium multiflorum were obtained from United Chemical and Allied Products, Calcutta, India through the Meer Corp., North Bergen, NJ. Gelonin $\left(M_{\mathrm{r}} 30,500\right)$ was purified as described previously (12). Seeds of Saponaria officinalis were purchased from Germania Seed Co., Chicago, IL, and the major ribosome-inactivating protein, termed here saporin $\left(M_{\mathrm{r}} 29,500\right)$, was purified from the seeds by the method of Stirpe et al. (14).

Preparation and purification of disulfide-linked conjugates between anti-T11 and the ribosome-inactivating proteins. Anti-T11 $(1 \mathrm{mg} / \mathrm{ml})$ in $100 \mathrm{mM}$ sodium phosphate buffer, $\mathrm{pH} 7.0$, containing EDTA (1 mM) was mixed with SPDP $(60 \mu \mathrm{M})$ added from a freshly made stock solution $(10 \mathrm{mM})$ in ethanol. The mixture was incubated at $30^{\circ} \mathrm{C}$ for $30 \mathrm{~min}$ and then dialyzed against the $\mathrm{pH} 7.0$ buffer to remove excess reagent. $\sim 2.3$ dithiopyridyl groups were incorporated per molecule of antibody, measured as described previously (15). Modification with succinimidyl $4-(N$-maleimidomethyl) cyclohexane-1-carboxylate (SMCC) to introduce maleimido groups was performed using similar conditions, and the maleimido groups introduced were measured as described previously (13).

Gelonin $(2 \mathrm{mg} / \mathrm{ml})$ in $60 \mathrm{mM}$ triethanolamine/ $\mathrm{HCl}$ buffer, $\mathrm{pH} 8.0$, containing EDTA $(1 \mathrm{mM})$ was treated with 2-iminothiolane $(1 \mathrm{mM})$ at $0^{\circ} \mathrm{C}$ for $90 \mathrm{~min}$ under argon, after the procedure described previously $(11,13)$. Excess reagent was removed by gel filtration at $4^{\circ} \mathrm{C}$ on a column of Sephadex G-25 (fine) equilibrated with $5 \mathrm{mM}$ bis-tris/acetate buffer, pH 5.8, containing $\mathrm{NaCl}(50 \mathrm{mM})$ and EDTA $(1 \mathrm{mM})$. $\sim 0.6-0.7$ sulfhydryl groups were added per gelonin molecule as determined by the method of Ellman (16). Saporin was modified with 2-iminothiolane using exactly the same conditions.

Conjugation of anti-T11 and ribosome-inactivating proteins was effected by mixing the modified anti-T11 in the $\mathrm{pH} 7.0$ buffer with an equal weight (equivalent to a fivefold molar excess) of the modified gelonin or the modified saporin in the $\mathrm{pH} 5.8$ buffer (13). The $\mathrm{pH}$ of the mixture was then raised to 7.0 by addition of $0.5 \mathrm{M}$ triethanolamine/ $\mathrm{HCl}$ buffer, $\mathrm{pH} 8.0$, and the conjugation reaction was allowed to proceed at $4^{\circ} \mathrm{C}$ for $20 \mathrm{~h}$ under argon.

The immunotoxin conjugates were purified from nonconjugated antibody, nonconjugated ribosome-inactivating proteins, and aggregates of high molecular weight by gel filtration through a column of Sephacryl S-300 followed by ion-exchange chromatography with carboxymethyl cellulose (Whatman CM-52, Whatman, Inc.) using conditions that are described in detail elsewhere (13). Polyacrylamide/dodecyl sulfate gels showed that the purified conjugate between anti-T11 and gelonin contained antibody linked to one $(\sim 60 \%)$, two $(\sim 30 \%)$, and three $(\sim 10 \%)$ molecules of gelonin and that the mixture did not contain nonconjugated antibody or nonconjugated gelonin $(11,13)$. The immunotoxin that contained saporin was similarly pure. The yield of immunotoxin was generally $\sim 40 \mathrm{mg}$ of purified conjugate, starting from $100 \mathrm{mg}$ of anti-T11.

The immunotoxin preparations were passed through a 2-ml column (for $\mathbf{4 0} \mathrm{mg}$ of protein in $\mathbf{4 0} \mathrm{ml}$ of phosphate-buffered saline [PBS]) of Detoxigel (Pierce Chemical Co.) at $4^{\circ} \mathrm{C}$ as a precaution to minimize endotoxin levels. The conjugates were then sterilized by passage through a $0.22-\mu \mathrm{m}$ filtration membrane (Millex-GV; Millipore Corp., Bedford, $\mathrm{MA})$ and tested for the presence of endotoxin using the Limulus Amebocyte Lysate test. Neither the binding activity of the antibody nor the ribosome-inactivating activity of the toxins were damaged by the conjugation reactions (13).

Protocol for anti-T11 and anti-T11-toxin infusions. Rhesus monkeys were sedated with ketamine throughout the infusion of the monoclonal antibodies and the antibody-toxin conjugates. Antibody or antibodytoxin conjugate was delivered intravenously by continuous infusion over a 4- $\mathrm{h}$ period in a $20-\mathrm{ml}$ volume. Heparinized blood samples were obtained before the start of the infusions, at $2 \mathrm{~h}$ into the infusions, $30 \mathrm{~min}$ and 2 $\mathrm{h}$ after the infusions, and daily thereafter. By using heparinized blood, we were able to study both isolated peripheral blood lymphocytes (PBL) and plasma from the same samples. We therefore have utilized plasma rather than serum in these experiments. Axillary and inguinal lymph node biopsies were performed under sterile conditions on ketamine anesthetized monkeys. Mesenteric lymph node and spleen biopsies were done at laparotomies on animals under general anesthesia.

Immunohistologic studies. Tissues obtained from surgical procedures were embedded in ornithine carbamyl transferase (OCT) embedding medium, snap frozen, sectioned using a freezing microtome, and the sections were subsequently fixed in acetone. The avidin-biotin immunoperoxidase technique was used for this staining. A commercially available kit (Vectastain ABC Kit; Vector Laboratories, Inc., Burlingame, CA) was used according to enclosed directions with minor modifications (17). For every tissue section examined for the presence of mouse antibody on cell membranes, the amount of staining with and without in vitro addition of anti-T11 were compared. This allowed us to determine the location and number of cells to which infused antibody was bound as well as the number of potential target lymphocytes in that tissue.

Toxin on the cell membrane of lymphocytes was detected by staining tissue sections with rabbit anti-gelonin or rabbit anti-saporin serum, then with biotinylated goat anti-rabbit Ig followed by avidin-biotin complex and diamino benzidine (DAB) with $3 \%$ hydrogen peroxide. The amount of staining without in vitro addition of anti-T11-toxin conjugate was compared with that seen after in vitro addition of conjugate.

Radioimmunoassay (RIA) for mouse Ig. Goat anti-mouse IgG or rabbit antiserum raised against each ribosome-inactivating protein was absorbed for $2 \mathrm{~h}$ at $4^{\circ} \mathrm{C}$ onto flexible polyvinyl microtiter plates (BectonDickinson \& Co., Oxnard, CA). Wells were then incubated with $1 \%$ bovine serum albumin (BSA) in PBS for $1 \mathrm{~h}$ to block nonspecific binding sites on the plastic and then were washed three times with PBS. Equal volumes of test plasma from the infused monkeys and ${ }^{125} \mathrm{I}$-labeled monoclonal mouse IgG or ribosome-inactivating protein were incubated in these wells for at least $1 \mathrm{~h}$ at room temperature. The wells were washed extensively, cut from the plate, and counted in an automated gamma counter.

\section{Results}

Plasma concentrations of mouse Ig and ribosome-inactivating protein. Our previous studies (11) indicated that intact disulfide linked anti-T11-ribosome-inactivating protein conjugates are detectable in monkey plasma after infusion. Those studies, however, showed that some breakdown of these conjugates does occur in the animals. To ascertain in a quantitative fashion the degree of instability of the conjugates in vivo, we directly measured the precise concentration of both mouse Ig and toxin in the plasma at multiple times after infusion of disulfide-linked conjugates. We also did similar studies on plasma from a monkey that received an antibody-toxin conjugate prepared using a thioether linkage which is not cleavable, and from a monkey that received unconjugated antibody.

We performed RIAs to measure mouse Ig and toxin present in plasma. Since free toxin is cleared almost immediately from the circulation, any measurable toxin in the plasma presumably represents intact conjugate. The results from five infusions, summarized in Table $\mathrm{I}$, show that the peak plasma concentration of monoclonal antibodies is substantially greater when unconjugated antibody is infused than when an equivalent quantity of antibody-toxin conjugate is delivered to the monkey. Furthermore, the plasma concentration of toxin declined at a faster rate than the concentration of anti-T11 following infusion. 16 $\mathrm{h}$ after infusion of disulfide-linked conjugates, $66-79 \%$ of mouse Ig present in plasma existed in the unconjugated form.

Fig. 1 illustrates the change in molar ratio of toxin to mouse 
Table I. Concentrations of Mouse IgG and Toxin in Plasma Following Immunotoxin Infusions

\begin{tabular}{|c|c|c|c|c|}
\hline $\begin{array}{l}\text { Toxin linked to anti-T11, } \\
\text { dosage of immunotoxin }\end{array}$ & $\begin{array}{l}\text { Time } \\
\text { postinfusion }\end{array}$ & $\begin{array}{l}\text { Mouse } \\
\text { IgG* }\end{array}$ & $\begin{array}{l}\text { Ribosome } \\
\text { inactivating* } \\
\text { protein }\end{array}$ & $\begin{array}{l}\text { Molar } \\
\text { ratio }\end{array}$ \\
\hline & $h$ & $\mu \mathrm{g} / \mathrm{ml}$ & $\mu \mathrm{g} / \mathrm{ml}$ & Toxin:Ig \\
\hline \multirow{3}{*}{$\begin{array}{l}\text { Anti-T11 unconjugated, } \\
1 \mathrm{mg} / \mathrm{kg}\end{array}$} & 2 & 72.0 & - & - \\
\hline & 16 & 29.4 & - & - \\
\hline & 40 & 17.4 & - & - \\
\hline \multirow{6}{*}{$\begin{array}{l}\text { Gelonin linked via thio- } \\
\text { ether bond, } 1 \mathrm{mg} / \mathrm{kg}\end{array}$} & Intrał & 4.2 & 1.85 & 2.35 \\
\hline & 0.5 & 12.3 & 4.20 & 1.82 \\
\hline & 2 & 9.0 & 1.59 & 0.94 \\
\hline & 16 & 3.5 & 0.46 & 0.70 \\
\hline & 40 & 1.2 & 0.10 & 0.44 \\
\hline & 64 & 0.9 & 0.14 & 0.83 \\
\hline \multirow{6}{*}{$\begin{array}{l}\text { Gelonin linked via disul- } \\
\text { fide bond, } 5 \mathrm{mg} / \mathrm{kg}\end{array}$} & Intra & 10.0 & 4.87 & 2.60 \\
\hline & 0.5 & 53.4 & 12.36 & 1.23 \\
\hline & 2 & 57.4 & 9.19 & 0.85 \\
\hline & 16 & 31.7 & 2.00 & 0.34 \\
\hline & 40 & 15.0 & 0.48 & 0.17 \\
\hline & 64 & 14.4 & 0.50 & 0.19 \\
\hline \multirow{6}{*}{$\begin{array}{l}\text { Saporin linked via disul- } \\
\text { fide bond, } 1 \mathrm{mg} / \mathrm{kg}\end{array}$} & Intra & 1.9 & 0.60 & 1.68 \\
\hline & 0.5 & 13.5 & 2.03 & 0.80 \\
\hline & 2 & 9.8 & 0.79 & 0.43 \\
\hline & 16 & 4.3 & 0.17 & 0.21 \\
\hline & 40 & 2.4 & 0.08 & 0.18 \\
\hline & 64 & 2.4 & 0.16 & 0.36 \\
\hline \multirow{5}{*}{$\begin{array}{l}\text { Saporin linked via disul- } \\
\text { fide bond, } 5 \mathrm{mg} / \mathrm{kg}\end{array}$} & Intra & 2.7 & 0.49 & 0.97 \\
\hline & 0.5 & 106.5 & 35.47 & 1.78 \\
\hline & 2 & 76.6 & 18.48 & 1.29 \\
\hline & 16 & 44.1 & 2.23 & 0.27 \\
\hline & 40 & 32.2 & 0.45 & 0.07 \\
\hline
\end{tabular}

* The limit of detection in the RIA was $0.1 \mu \mathrm{g} / \mathrm{ml}$ for mouse $\mathrm{IgG}$ and $0.01 \mu \mathrm{g} / \mathrm{ml}$ for immunotoxin. $¥$ Sample taken at midpoint of the infusion.

Ig after infusion of each immunotoxin at different dosages. The ratio declined from $\sim 1.5$ to $0.25-0.35$ in $16 \mathrm{~h}$ in the case of the disulfide-linked conjugates. The ratio of toxin to mouse Ig for the immunotoxin synthesized with a noncleavable linkage also declined rapidly, to near $1: 1$ within the first $2 \mathrm{~h}$ after infusion.

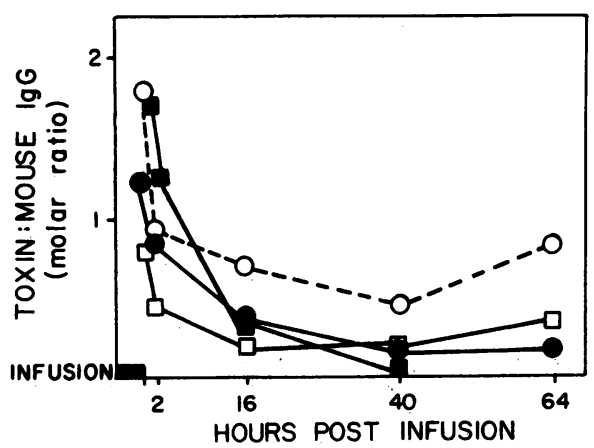

Figure 1. The ratio of molar concentrations of toxin to mouse Ig in plasma after immunotoxin infusions $\left(-O_{-}\right.$, Gelonin, thioether linked, $1 \mathrm{mg} / \mathrm{kg} ;-\bullet-$, Gelonin, disulfide linked, $5 \mathrm{mg} / \mathrm{kg} ;-\square-$, Saporin, disulfide linked, $1 \mathrm{mg} / \mathrm{kg}$; - --, Saporin, disulfide linked, $5 \mathrm{mg} / \mathrm{kg}$ ).
After $2 \mathrm{~h}$, the ratio decreased more slowly than for the disulfidelinked conjugates. It is likely that immunotoxin species with more than one gelonin or saporin per antibody were preferentially removed from circulation, thus causing an initial rapid decrease in toxin to mouse Ig ratio irrespective of the nature of the linker.

Infusions of unconjugated monoclonal anti-T11 antibody. Preliminary studies were then done to determine the feasibility of delivering unconjugated monoclonal anti-T11 antibody to $T$ lymphocytes in the lymph nodes and spleen of the rhesus monkey. Anti-T11 was infused into a monkey and mesenteric lymph nodes and a wedge of spleen were removed at a laparotomy and were snap frozen. Tissue sections were prepared and stained with either monoclonal anti-T11 antibody, then biotinylated horse anti-mouse Ig followed by avidin-biotin complex and DAB with 3\% hydrogen peroxide or the same sequence of reagents without the initial antibody. We could thus determine the amount of staining seen without in vitro addition of anti-T11 as compared with that seen with maximal staining in vitro of these target cells. This allowed us to determine the location and number of cells to which infused antibody was bound as compared with the number of potential target lymphocytes in that tissue. We found that $40 \mathrm{~h}$ after the infusion of anti-T11 at a dose of $0.2 \mathrm{mg} / \mathrm{kg}$, no staining of lymph node $T$ cells was seen. However, anti-T11 was detected on cells in the spleen, both in perivascular clusters and individually scattered throughout the remainder of the spleen (Fig. 2). The infused antibody was seen covering virtually all splenic $\mathrm{T}$ lymphocytes but was not present on B lymphocytes.

A similarly performed study was done after a $1.0 \mathrm{mg} / \mathrm{kg}$ infusion of monoclonal anti-T11 antibody in another monkey to determine if the infusion of a higher dose of antibody would result in lymph node $T$ cell staining. Again, virtually all splenic $T$ lymphocytes were coated with the infused anti-T11 monoclonal antibody by $40 \mathrm{~h}$ after the infusion. After this higher-dose infusion, $T$ cell coating by antibody was readily detectable in mesenteric lymph nodes (Fig. 3). The staining of the T cells in sections without in vitro addition of anti-T11 was a bit fainter than similar sections stained in vitro with anti-T11, suggesting that not all the binding sites on the $T$ cells were saturated after antibody infusion. Furthermore, not all the $T$ cells scattered throughout the germinal centers were coated by infused antiT11 antibody.

We then infused the B cell-specific monoclonal antibody anti-B1 into a rhesus monkey in a similar fashion to determine the extent to which the in vivo localization of an anti-lymphocyte antibody is immunologically specific. $40 \mathrm{~h}$ after a $1 \mathrm{mg} / \mathrm{kg}$ infusion of anti-B1, lymph node germinal center B cells but not paracortical $\mathrm{T}$ cells were coated with the infused antibody (Fig. 4). Thus, the infused $B$ and $T$ lymphocyte specific monoclonal antibodies bind with remarkable specificity to their target cell populations in vivo.

An infusion of monoclonal anti-T11 antibody at a dose of $1.0 \mathrm{mg} / \mathrm{kg}$ was then done in another monkey and repeated splenic and lymph node biopsies were performed over the ensuing $4 \mathrm{~d}$ to follow the fate of the infused antibody. By $16 \mathrm{~h}$ after infusion, virtually all lymph node $T$ cells were coated with infused antiT11 antibody. T lymphocytes in the lymph node removed $40 \mathrm{~h}$ after infusion were similarly coated with antibody. By $72 \mathrm{~h}$ after the infusion, while all the lymph node $T$ cells were coated with antibody, the staining of cells in sections without in vitro addition 

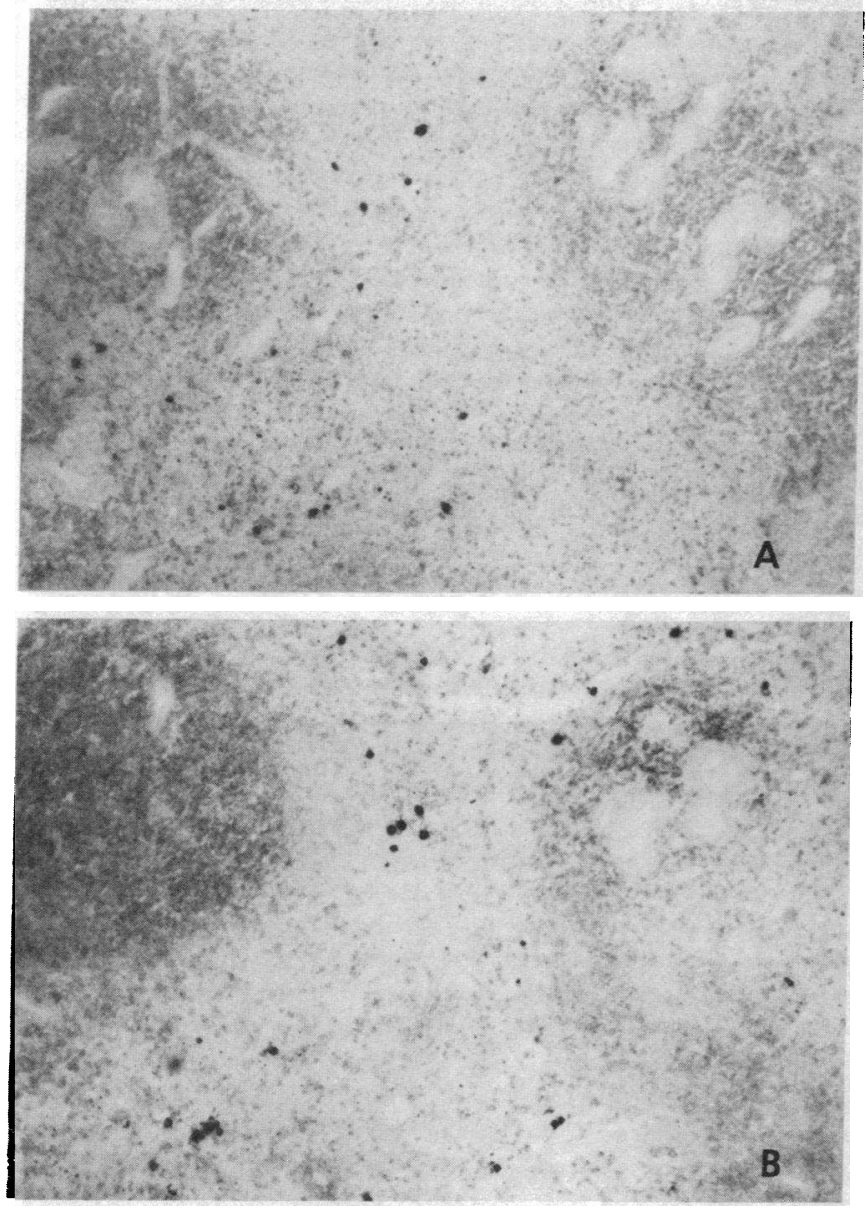

Figure 2. Consecutive sections of spleen biopsied $40 \mathrm{~h}$ after infusion of $0.2 \mathrm{mg} / \mathrm{kg}$ unconjugated anti-T11 developed for the presence on the cells of $(A)$ mouse Ig without in vitro addition of anti-T11, compared with $(B)$ mouse Ig with in vitro addition of anti-T11. Avidin-biotin immunoperoxidase. $\times 112$.

of anti-T11 was fainter than in sections stained in vitro with anti-T11, which suggests that binding sites for anti-T11 antibody were no longer saturated with the infused antibody. $96 \mathrm{~h}$ after infusion, only faint staining of $T$ cells was detectable in the biopsied lymph node.

Parallel changes were noted in sequential splenic biopsies. At $16 \mathrm{~h}$ after infusion virtually every splenic $T$ cell was maximally coated with the infused monoclonal anti-T11 antibody. By 72 h somewhat fewer splenic $T$ cells were stained by the infused antibody than could be detected by the in vitro addition of monoclonal anti-T11 antibody. Furthermore, the coated splenic $T$ cells stained less intensely than did the $T$ cells in sections onto which anti-T11 antibody was added in vitro.

The plasma concentration of monoclonal anti-T11 antibody in this animal reached a maximum of $72 \mu \mathrm{g} / \mathrm{ml} 2 \mathrm{~h}$ after infusion, fell to $29 \mu \mathrm{g} / \mathrm{ml} 16 \mathrm{~h}$ after infusion and to $17 \mu \mathrm{g} / \mathrm{ml} 40 \mathrm{~h}$ after infusion.

Infusion of noncleavably linked monoclonal anti-T11-ribosome-inactivating protein conjugate. We then sought to establish whether we could target ribosome-inactivating protein toxins to
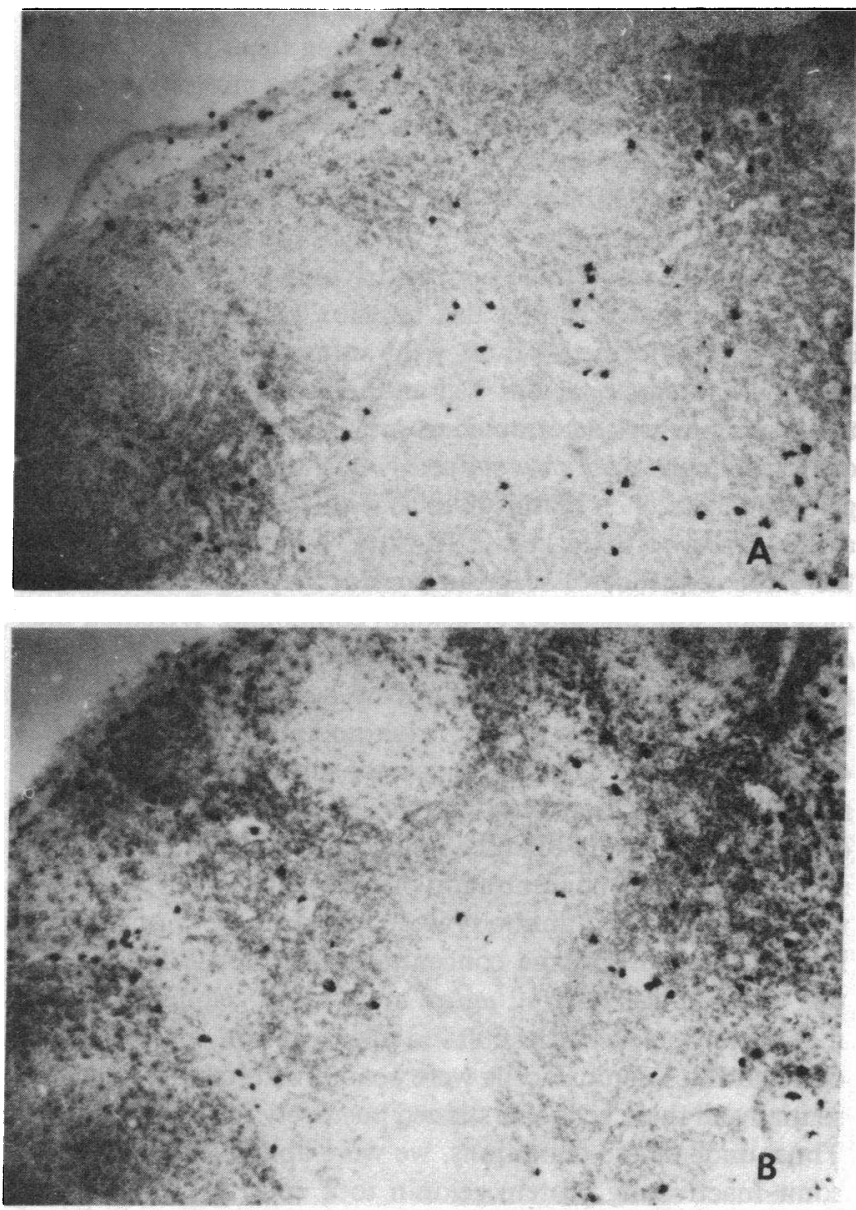

Figure 3. Consecutive sections of mesenteric lymph node biopsied 40 $\mathrm{h}$ after infusion of $1 \mathrm{mg} / \mathrm{kg}$ unconjugated anti-T11 developed as described in Fig. 2, $(A)$ without in vitro addition of anti-T11, and $(B)$ with in vitro addition of anti-T11. Avidin-biotin immunoperoxidase. $\times 112$.

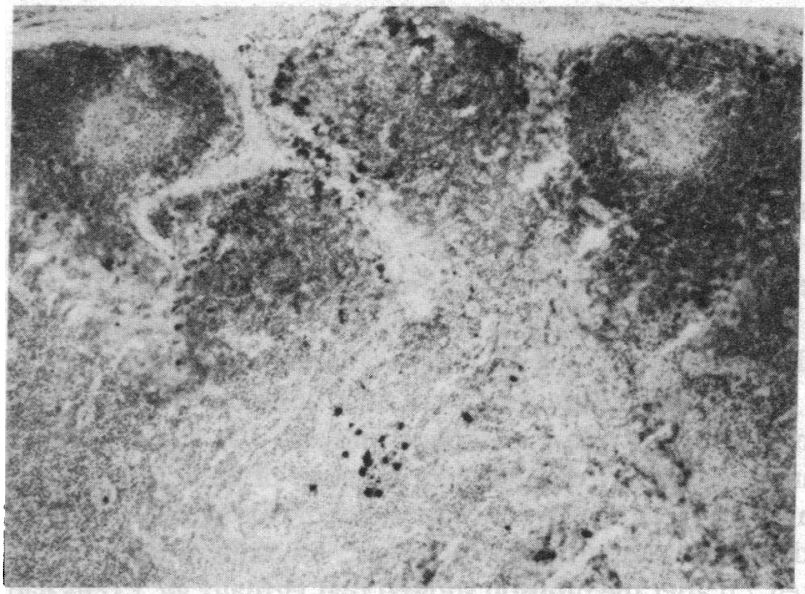

Figure 4. Section of mesenteric lymph node biopsied $40 \mathrm{~h}$ after infusion of $1 \mathrm{mg} / \mathrm{kg}$ unconjugated anti-B1 developed for the presence on the cells of mouse Ig without in vitro addition of anti-B1. Avidin-biotin immunoperoxidase. $\times 100$. 
a restricted lymphocyte population in the lymph nodes and spleen of the rhesus monkey by delivering them conjugated to a monoclonal antibody. We chose to perform our initial studies using an antibody-toxin conjugate prepared with a noncleavable thioether linkage to optimize our likelihood of detecting toxin on the targeted lymphocyte population. A rhesus monkey received a $1 \mathrm{mg} / \mathrm{kg}$ infusion of a monoclonal anti-T11-gelonin conjugate linked by a thioether bond; lymph node biopsies were performed 2 and $4 \mathrm{~d}$ after this infusion and a splenic wedge biopsy was performed $4 \mathrm{~d}$ after the infusion. The presence of the mouse monoclonal anti-T11 antibody on the T cells in these tissue sections was determined as previously described. The biopsy specimens were also stained with a high titer rabbit antigelonin serum, then biotinylated goat anti-rabbit Ig followed by avidin-biotin complex and DAB with $3 \%$ hydrogen peroxide or the same sequence of reagents preceded by an initial in vitro incubation with the anti-T11-gelonin compound. We could thus determine the location and number of potential target cells in the tissue sections. Neither mouse antibody nor toxin were detectable on the $T$ cells of the lymph node biopsies taken 2 and $4 \mathrm{~d}$ after infusion. This is perhaps not surprising in light of our recent demonstration that infusion of two to three times the quantity of antibody-toxin conjugates is needed to achieve the same peak plasma concentration of antibody that can be reached when unconjugated antibody is delivered to the monkey (11). In fact, the peak plasma concentration of mouse Ig following this infusion was only $12 \mu \mathrm{g} / \mathrm{ml}$ and that of gelonin was $4 \mu \mathrm{g} /$ $\mathrm{ml}$ (Table I). Nevertheless, at $4 \mathrm{~d}$ after infusion, approximately one-half the splenic $\mathrm{T}$ cells were coated with mouse Ig and essentially all these cells also stained positively for gelonin as well. Thus, under these conditions, we were able to target the ribosome-inactivating protein gelonin to $\mathrm{T}$ cells in the spleen but not in lymph nodes.

Infusions of disulfide-linked anti-T11-ribosome-inactivating protein conjugates. We have previously shown that, while a conjugate of an antibody and gelonin is cytotoxic in vitro when these proteins are linked by cleavable disulfide bonds, a similar antibody-gelonin conjugate demonstrates little in vitro cytotoxicity when those proteins are linked by a noncleavable thioether bond (13). Since our goal in the use of immunotoxins is to kill restricted cell populations in the living animal, we proceeded to repeat a similar infusion using a disulfide-linked immunotoxin conjugate. The first such study was done using anti-T11 linked by a disulfide bond to saporin, delivered at a dose of $1 \mathrm{mg} / \mathrm{kg}$. As in the previous study of the $1 \mathrm{mg} / \mathrm{kg}$ thioether-linked antibody-toxin conjugate, very little mouse Ig or toxin were detected in sections of lymph nodes taken 2 and $4 \mathrm{~d}$ after infusion. In the splenic biopsy taken $4 \mathrm{~d}$ after the infusion, virtually all the splenic $\mathrm{T}$ cells demonstrated mouse $\mathrm{Ig}$ bound to them, although the staining was not of maximal intensity. Saporin was detected with only faint staining on some of these splenic $\mathrm{T}$ cells.

Similar single infusions were then done on monkeys with $5 \mathrm{mg} / \mathrm{kg}$ doses of anti-T11-saporin and anti-T11-gelonin. In the animal that received a $5 \mathrm{mg} / \mathrm{kg}$ infusion of anti-T11-saporin, peak plasma antibody concentrations of $106 \mu \mathrm{g} / \mathrm{ml}$ mouse Ig and $35 \mu \mathrm{g} / \mathrm{ml}$ saporin were achieved. An axillary lymph node taken $2 \mathrm{~d}$ after the infusion showed that virtually all $\mathrm{T}$ cells had bound a maximal amount of antibody and these same $T$ cells also stained for the presence of saporin (Fig. 5). Sections of an axillary and mesenteric lymph node taken $4 \mathrm{~d}$ after the infusion still demonstrated maximal staining of all $\mathrm{T}$ cells for mouse Ig,
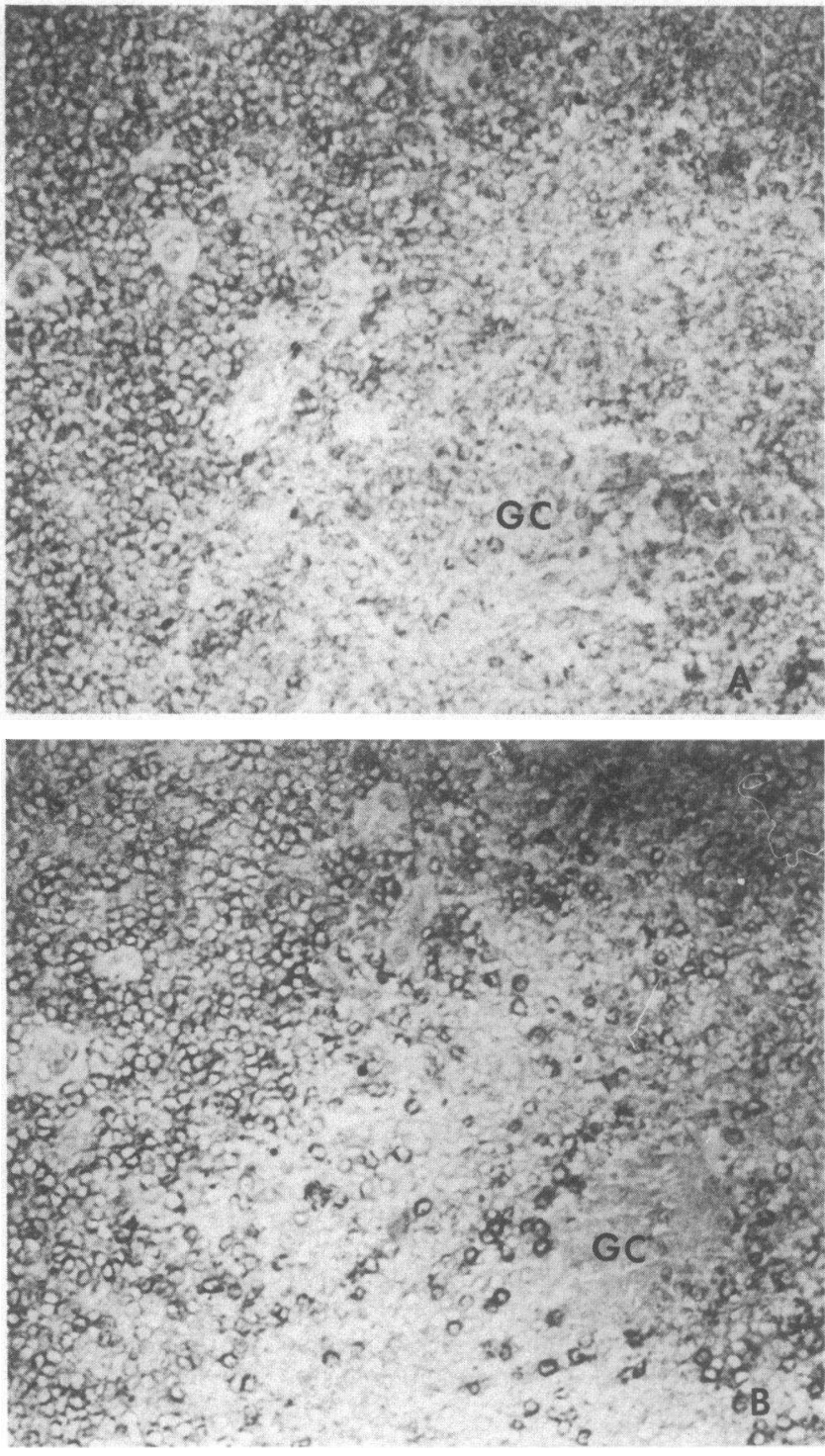

Figure 5. Consecutive sections of axillary lymph node biopsied $2 \mathrm{~d}$ after infusion of $5 \mathrm{mg} / \mathrm{kg}$ anti-T11-saporin conjugate, $(A)$ without in vitro addition of anti-T11-saporin conjugate, and $(B)$ with addition in vitro of anti-T11-saporin conjugate, developed for the presence of saporin on the cells with rabbit anti-saporin serum followed by biotinylated anti-rabbit Ig, then avidin-biotin complex and DAB with $3 \%$ $\mathrm{H}_{2} \mathrm{O}_{2}$. GC, germinal center. $\times 310$.

yet now only a small amount of toxin could be detected on their surface.

Parallel studies in the monkey infused with $5 \mathrm{mg} / \mathrm{kg}$ antiT11-gelonin gave very similar results. All the $T$ cells in an axillary lymph node taken $2 \mathrm{~d}$ after the infusion stained positively for mouse Ig and toxin (not shown). The $T$ cells in both axillary and mesenteric node biopsies taken $4 \mathrm{~d}$ after the infusion still demonstrated staining for mouse Ig but in this experiment no toxin could now be detected on their surface.

The spleen biopsy, taken $4 \mathrm{~d}$ after the infusion with $5 \mathrm{mg} /$ kg of anti-T11-gelonin, demonstrated optimal staining for the presence of bound mouse Ig on $\mathrm{T}$ cells. Occasional areas showed that the same $\mathrm{T}$ lymphocytes also stained for the presence of gelonin (Fig. 6). However, most of the $T$ cell areas showed fewer 

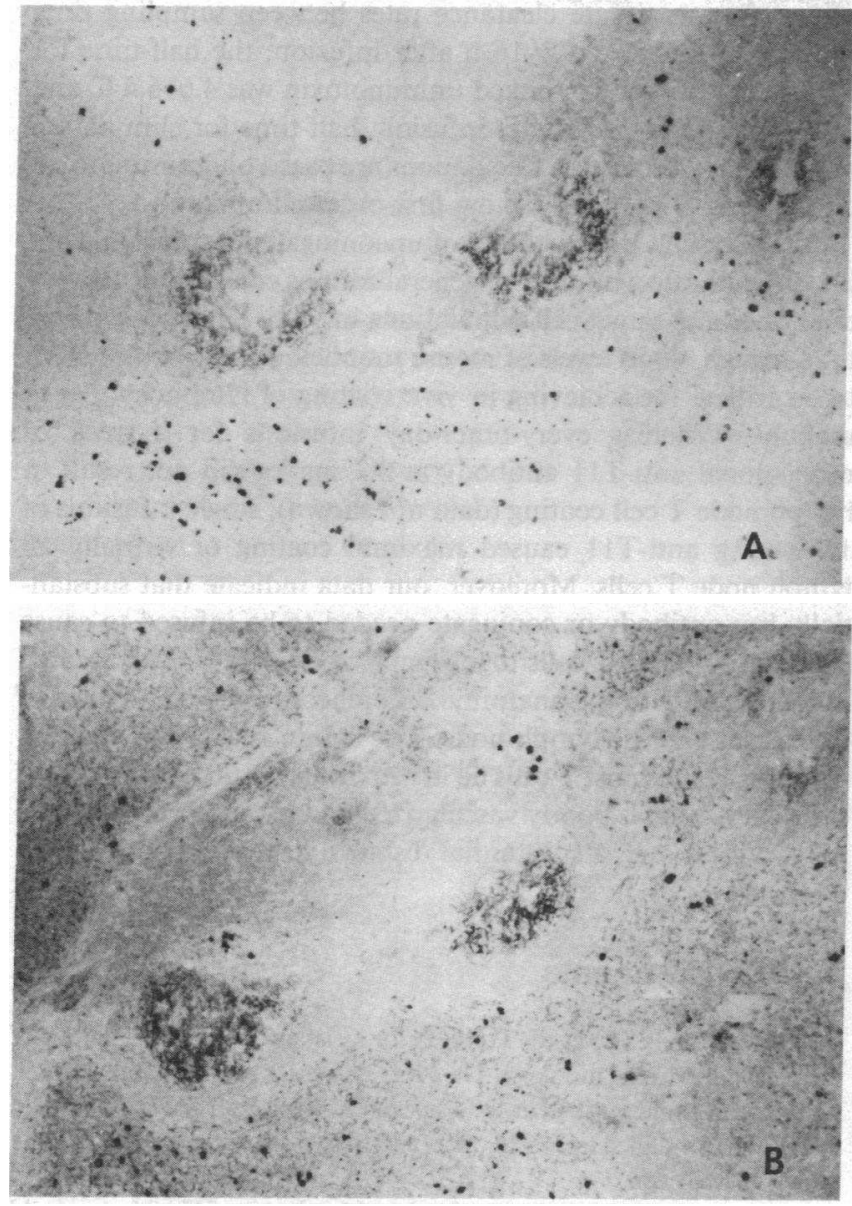

Figure 6. Consecutive sections of three periarteriolar $\mathrm{T}$ cell sheaths in a spleen biopsied $4 \mathrm{~d}$ after infusion of anti-T11-gelonin conjugate at 5 $\mathrm{mg} / \mathrm{kg}$, developed for the presence on the cells of $(A)$ mouse Ig as described in legend of Fig. $2 A$, and $(B)$, gelonin by staining with rabbit anti-gelonin serum followed by biotinylated anti-rabbit Ig, then avidin-biotin complex and DAB with $3 \% \mathrm{H}_{2} \mathrm{O}_{2} . \times 112$.

T lymphocytes staining for the presence of gelonin than for mouse Ig and this staining for gelonin was clearly less intense than that seen in tissue sections onto which anti-T11-gelonin was added in vitro (Fig. 7). Similarly, while all the splenic $T$ cells demonstrated maximal binding of the infused mouse Ig 4 d after delivery of the anti-T11-saporin, very few of these cells had detectable saporin on their surface (not shown). These data are consistent with our previous demonstration that the disulfidelinked antibody-toxin conjugates are not fully stable in vivo. Nevertheless, we have been able to show clearly that toxins can be delivered to virtually all $\mathrm{T}$ cells in lymphoid tissue.

\section{Discussion}

We previously examined the effects of various monoclonal anti$T 11$ antibodies on the circulating $T$ cell pool in the rhesus monkey (10). Infusions of these antibodies resulted in the coating of circulating $T$ lymphocytes with antibody, the modulation of $T 11$ off the $T$ cell surface, and the transient clearance of $T$ cells from the circulation. Yet, a significant variation was seen in the extent to which these changes occurred with each of the different an-
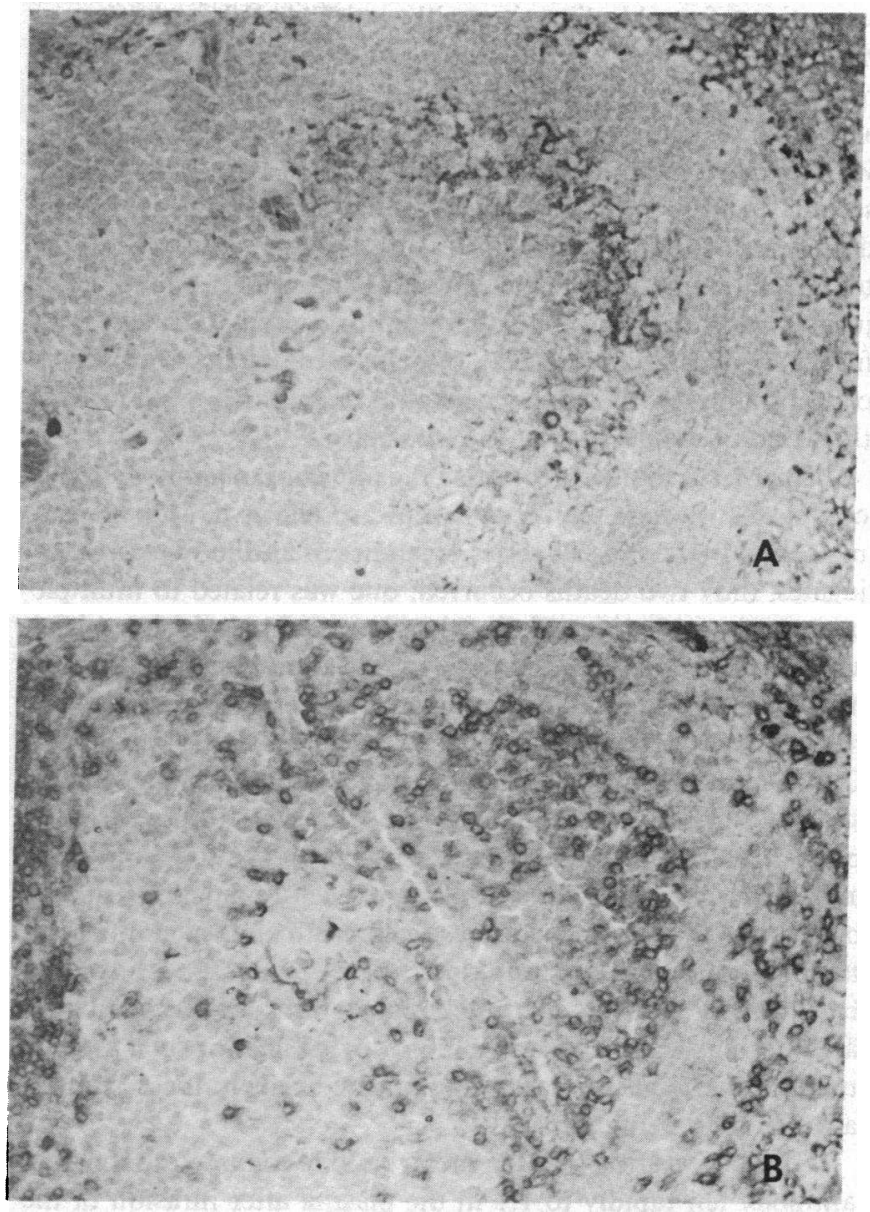

Figure 7. Consecutive sections of a periarteriolar sheath in the spleen biopsied $4 \mathrm{~d}$ after infusion of anti-T11-gelonin conjugate at $5 \mathrm{mg} / \mathrm{kg}$, $(A)$ without in vitro addition of anti-T11-gelonin conjugate and $(B)$ with addition of in vitro anti-T11-gelonin conjugate, developed as described in Fig. 6. $\times 280$.

tibodies. One of these antibodies was selected for conjugation to A chain toxins as model immunotoxins for in vivo studies. This particular anti-T11 antibody was rapidly cleared from the serum after infusion, was inefficient in eliminating $T$ cells from the circulation, and did not cause a rapid modulation of the $\mathrm{T} 11$ antigen from the $\mathrm{T}$ lymphocyte surface membrane in vitro. Using this antibody, we showed that concentrations of disulfidelinked anti-T11-toxin conjugate remain intact in the circulation of the rhesus monkey after a single intravenous infusion (11). Moreover, this intact conjugate was shown to be functional in the plasma of the infused animals in an in vitro cytotoxicity assay (11).

We have now shown that, after a single infusion of $1 \mathrm{mg} / \mathrm{kg}$ monoclonal anti-T11 antibody, which results in a peak plasma concentration of $\sim 70 \mu \mathrm{g} / \mathrm{ml}$ mouse antibody by $2 \mathrm{~h}$ after infusion, all $\mathrm{T}$ lymphocytes in the lymph nodes and spleens of healthy rhesus monkeys were coated with the infused mouse Ig. This coating was maximal at $16 \mathrm{~h}$ and had decreased by $72 \mathrm{~h}$ after infusion. Because derivatized antibody is cleared more rapidly than unconjugated antibody (11), it was necessary to infuse a higher dose of immunotoxin than antibody alone to achieve 
saturation of the binding sites with anti-T11. When that saturation was achieved with $5 \mathrm{mg} / \mathrm{kg}$ antibody-toxin conjugates, resulting in plasma concentrations of $57-106 \mu \mathrm{g} / \mathrm{ml}$ antibody and $12-35 \mu \mathrm{g} / \mathrm{ml}$ toxin by $2 \mathrm{~h}$ after infusion, ribosome-inactivating protein was readily demonstrable on lymph node and spleen $T$ cells by $16 \mathrm{~h}$ after infusion. Interestingly, mouse Ig was detected on target $T$ cells $4 \mathrm{~d}$ after infusion, at a time when little toxin binding could be detected. This suggests that these conjugates break down in time after administration. This was confirmed in a quantitative fashion by demonstrating that the plasma concentration of ribosome-inactivating protein fell more rapidly than that of mouse Ig after the infusions.

The rhesus monkeys tolerated the infusions of antibody-toxin conjugates without significant untoward effects. Of the 18 animals used in the present series of studies of antibody-toxin conjugates, only two deaths occurred; one was related to multiple prolonged anesthesias and the other, in an animal which received a low dose infusion, was due to intrahepatic hemorrhage. The histologic appearance of lymph node and spleen sections did not, however, suggest any damage to the target $T$ cell populations. Our demonstration that ribosome-inactivating proteins can be successfully delivered with exquisite specificity to target $T$ cell populations in the monkey suggests that, if the toxins utilized are potent enough, killing of restricted cell populations should be feasible. Histologic evidence of cell death after such infusions may not be manifested until later than 72 h. It may, however, be necessary to assess the functional status of the targeted cells after conjugate infusions to show a toxic effect of such a treatment. Functional studies on the targeted cells in these animals are currently being pursued.

The observation that the molar ratio of toxin to monoclonal antibody fell rapidly to $1: 1$ in the plasma after infusion of the noncleavably linked immunotoxin suggests that conjugates containing two and three toxin molecules per antibody (such conjugates constituted $\sim 40 \%$ of the infused immunotoxin) may be cleared much more rapidly (within $2 \mathrm{~h}$ ) than simple dimeric conjugates. The ratio of toxin to mouse Ig for the disulfidelinked immunotoxins continued to fall to low values of $0.1-0.2$ in 1-2 $\mathrm{d}$ after infusion, consistent with our previous demonstration that the disulfide linked conjugates are not completely stable in vivo (11). The ratio of toxin to mouse Ig decreased to values somewhat less than 1.0 after infusion of the noncleavable immunotoxin (Fig. 1), although the ratio was always much higher than those after infusions of the disulfide-linked conjugates at later time points. This decrease in toxin/mouse Ig ratio to $<1.0$ is readily explained. As much as $5 \%$ of the infused immunotoxin preparations can be unconjugated antibody which may escape detection by polyacrylamide gel electrophoresis. Having a longer circulation elimination half-time than conjugated antibody (11), the free antibody should constitute an increasing fraction of the infused material at late points after infusion.

A number of factors affect the circulatory elimination of immunotoxins and therefore result in plasma clearance that does not follow strict first-order kinetics. These factors include the preferential excretion of immunotoxin species containing more than one toxin molecule, the redistribution of immunotoxin to antibody binding sites, the cleavage of the disulfide linkages followed by extremely rapid excretion of free toxin, as well as excretion of entire immunotoxin molecules. If, however, we assume that toxin measurable in plasma $2 \mathrm{~h}$ after infusion represents mostly dimeric immunotoxin, the data in Table I allow calcu- lation of approximate clearance rates between sampling time points. For the period $2-16 \mathrm{~h}$ after infusion, the half-time for elimination of disulfide-linked immunotoxin was 4.6-6.4 h, and for the period $16-40 \mathrm{~h}$ after infusion, half-time for elimination was 10.4-11.7 h. (These calculations are based on immunotoxin infusions of $5 \mathrm{mg} / \mathrm{kg}$ assuming first-order elimination.)

Our findings in the studies of unconjugated monoclonal antibodies indicate a number of generalizations concerning delivery of antibody to target cell populations in vivo. High peak rather than trough blood levels of mouse monoclonal antibodies seem to be critical for achieving in vivo coating of lymphocyte populations. Whereas every-other-day infusions for a week of monoclonal anti-T11 antibody at $0.2 \mathrm{mg} / \mathrm{kg}$ did not result in lymph node $\mathrm{T}$ cell coating (data not shown), single infusions of $1.0 \mathrm{mg} / \mathrm{kg}$ anti-T11 caused maximal coating of virtually all lymph node T cells. Moreover, our data indicate that substantially less antibody or conjugate needed to be infused to cause coating of splenic $T$ cells than lymph node $T$ cells. This finding is consistent with the anatomic differences in the circulation of the spleen and the lymph node. The spleen is a highly vascular organ in which most $\mathrm{T}$ cells lie in proximity to circulating blood; the lymph node is poorly vascularized and blood-borne products must diffuse over a substantial distance to reach nodal $\mathrm{T}$ lymphocytes.

\section{Acknowledgments}

We wish to thank Dr. Louis J. Guida for assistance in administration of the antibodies to the monkeys, Dr. Peter D. Senter for providing purified saporin and some purified anti-T11-saporin conjugate, Joanne Yetz and Gail Butler for skilled technical work, and Bettye-Jean Roy for preparation of this manuscript.

This work was supported by National Institutes of Health grants AI 20729 and RR00168, and by funds provided by Immunogen, Inc., Boston, MA. Dr. Letvin received an American Cancer Society Junior Faculty Award. Dr. Ritz is a Scholar of the Leukemia Society of America.

\section{References}

1. Vitetta, E. S., and J. W. Uhr. 1985. Immunotoxins: redirecting nature's poisons. Cell. 41:653-654.

2. Ramakrishnan, S., and S. Houston. 1985. Immunological and biological stability of immunotoxins in vivo as studied by the clearance of disulfide-linked pokeweed antiviral protein-antibody conjugates from blood. Cancer Res. 45:2031-2036.

3. Uhr, J. S. 1984. Immunotoxins: harnessing nature's poisons. J. Immunol. 133:i-x.

4. Haynes, B. F., B. L. Dowell, L. L. Hensley, I. Gore, and R. S. Metzgar. 1982. Human $\mathrm{T}$ cell antigen expression by primate $\mathrm{T}$ cells. Science (Wash. DC). 215:298-300.

5. Letvin, N. L., N. W. King, E. L. Reinherz, R. D. Hunt, H. Lane, and S. F. Schlossman. 1983. T lymphocyte surface antigens in primates. Eur. J. Immunol. 13:345-347.

6. Letvin, N. L., R. F. Todd III, L. S. Palley, S. F. Schlossman, and J. D. Griffin. 1983. Conservation of myeloid surface antigens on primate granulocytes. Blood. 61:408-410.

7. Letvin, N. L., W. R. Aldrich, D. A. Thorley-Lawson, S. F. Schlossman, and L. M. Nadler. 1984. Surface antigen changes during B-lymphocyte activation in primates. Cell. Immunol. 84:163-170.

8. Palley, L. S., S. F. Schlossman, and N. L. Letvin. 1984. Common tree shrews and primates share leukocyte membrane antigens. $J$. Med. Primatol. 13:67-71.

9. Meuer, S. C., R. E. Hussey, M. Fabbi, D. Fox, O. Acuto, K. A. Fitzgerald, J. C. Hodgdon, J. P. Protentis, S. F. Schlossman, and E. L. 
Reinherz. 1984. An alternative pathway of T-cell activation: a functional role for the $50 \mathrm{Kd} \mathrm{T} 11$ sheep erythrocyte receptor protein. Cell. 36:897906.

10. Letvin, N. L., J. Ritz, L. J. Guida, J. M. Yetz, J. M. Lambert, E. L. Reinherz, and S. F. Schlossman. 1985. In vivo administration of lymphocyte-specific monoclonal antibodies in nonhuman primates. I. Effects of anti-T11 antibodies on the circulating T cell pool. Blood. 66: 961-966.

11. Letvin, N. L., V. S. Goldmacher, J. Ritz, J. M. Yetz, S. F. Schlossman, and J. M. Lambert. 1986. In vivo administration of lymphocyte-specific monoclonal antibodies in nonhuman primates. In vivo stability of disulfide-linked immunotoxin conjugates. J. Clin. Invest. 77: 977-984.

12. Stirpe, F., S. Olsnes, and A. Pihl. 1980. Gelonin, a new inhibitor of protein synthesis, non-toxic to intact cells. J. Biol. Chem. 255:69476952.

13. Lambert, J. M., P. D. Senter, A. Yau-Young, W. A. Blattler, and V. S. Goldmacher. 1985. Purified immunotoxins that are reactive with human lymphoid cells: monoclonal antibodies conjugated to the ribosome-inactivating proteins gelonin and the pokeweed antiviral proteins. J. Biol. Chem. 260:12035-12041.

14. Stirpe, F., A. Gasperi-Campani, L. Barbieri, A. Falasca, A. Abbondanza, and W. A. Stevens. 1983. Ribosome-inactivating proteins from the seeds of Saponaria officinalis L. (soap wort), of Agrostemma githago L. (corn cockle) and of Asparagus officinalis L. (asparagus), and from the latex of Hura crepitans L. (sandbox tree). Biochem. J. 216: 617-625.

15. Carlsson, J., H. Drevin, and R. Axen. 1978. Protein thiolation and reversible protein-protein conjugation. $N$-Succinimidyl 3-(2-pyridyldithio)propionate, a new heterobifunctional reagent. Biochem. J. 173: 723-737.

16. Ellman, G. L. 1959. Tissue sulfhydryl groups. Arch. Biochem. Biophys. 82:70-77.

17. Chalifoux, L. V., S. F. Schlossman, and N. L. Letvin. 1984. Delineation of lymphocyte subsets in lymph nodes of non-human primates. Clin. Immunol. Immunopathol. 31:96-101. 